\title{
Pariwisata dan Pengembangan Sumberdaya Manusia
}

\author{
Oleh : Nandi
}

\begin{abstract}
Abstrak
Sektor pariwisata merupakan salah satu sektor andalan pemerintah Indonesia untuk menghasilkan devisa negara, oleh karena itu pemanfaatan, pengembangan, pengelolaan dan pembiayaan kawasan wisata harus mendapat perhatian yang serius dari pemerintah dengan melibatkan peran lembaga-lembaga pemerintah, stakes holder yang terkait serta partisipasi seluruh lapisan masyarakat dalam berbagai kebijakan dan program yang akan diambil. Dalam makalah ini pembahasan mengenai kawasan wisata lebih difokuskan pada penguraian konsep dan praktek good governance, proses dan prosedur kelembagaan, pembiayaan pembangunan untuk pengembangan sektor pariwisata yang dikaitkan dengan pendidikan untuk meningkatkatkan kualitas sumberdaya manusia (SDM) di bidang kepariwisataan. Kajian terhadap pengembangan kawasan wisata di Indonesia berdasarkan pada kajian pustaka yang berkaitan dengan permasalahan-permasalahan yang timbul dari pengembangan kawasan wisata merupakan materi yang akan dibahas dalam makalah ini.
\end{abstract}

Kata Kunci: Pengembangan Pariwisata, Pendidikan Kepariwisataan, Sumberdaya Manusia

*) Nandi, S.Pd., adalah dosen Jurusan Pendidikan Geografi FPIPS UPI

\section{A. Latar Belakang}

Indonesia merupakan negara kepulauan terbesar di dunia, dengan \pm 18.110 pulau yang dimilikinya dengan garis pantai sepanjang $108.000 \mathrm{~km}$. Negara Indonesia memiliki potensi alam, keanekaragaman flora dan fauna, peninggalan purbakala, peninggalan sejarah, serta seni dan budaya yang semuanya itu merupakan sumber daya dan modal yang besar artinya bagi usaha pengembangan dan peningkatan kepariwisataan. Modal tersebut harus dimanfaatkan secara optimal melalui penyelenggaraan kepariwisataan yang secara umum bertujuan untuk meningkatkan pendapatan nasional dalam rangka meningkatkan kesejahteraan rakyat.

Menurut data statistik, tercatat bahwa sektor pariwisata memberikan kontribusi yang cukup besar terhadap perekonomian nasional. Tahun 2002 target perolehan devisa sebesar US \$ 5,8 
M untuk 5,8 juta wisman, dan tahun 2003 US \$ 6,3 M 6,9 juta wisman, sedangkan target 2004 US 7,5 M (Widibyo, 2000). Dengan potensi wisata yang dimiliki masih memungkinkan peluang peningkatan penerimaan negara dari sektor pariwisata (Dirjen -pariwisata,2004)

Berdasarkan uraian diatas pembangunan dan program pengembangan pariwisata memainkan peranan yang sangat penting dalam strategi pembangunan ekonomi di suatu Negara atau daerah. Hal ini disebabkan sumbangan sektor pariwisata dalam pembangunan ekonomi nasional menurut Spillane (1994) dapat diukur dengan mudah dari berbagai macam tolok ukur. Dimana hal yang paling penting adalah mengenai sumbangan pada neraca pembayaran, pendapatan nasional (GDP), penciptaan lapangan kerja dan sektor-sektor ikutan lainnya dari sektor pariwisata.

Untuk itu, program pembangunan pariwisata dapat diprioritaskan sebagai bagian terpenting dari strategi pembangunan ekonomi jangka panjang, menengah dan jangka pendek dari pemerintah pusat dan pemerintah daerah. Menurut Hessel Nogi S Tangkilisan (2002) hal ini meliputi :

1. Pengembangan perwilayahan, pengelompokan obyek dan daya tarik wisata.

2. Pengembangan produk wisata.

3. Pengembangan jaringan transportasi/aksesibilitas antar kawasan, daerah dan internasional.

4. Pengembangan pusat jaringan publik.

Berdasarkan pemahaman konsep pembangunan kepariwisataan diatas, maka usaha pemerintah daerah membangun periwisata tidak lepas dari upaya meningkatkan PAD seperti retiribusi karcis masuk objek wisata, retribusi penjualan, parkir dan retribusi perijinan usaha serta pajak hiburan, hotel dan restoran. Sedangkan perluasan kesempatan berusaha misalnya penambahan hotel, restoran, caffe, usaha dibidang hiburan, perusahaan travel, produsen dan penjual (toko) barang cindramata, Pedagang Kaki Lima (PKL) dan lain sebagainya. Dengan berkembangnya usaha ekonomi kepariwisataan tersebut maka akan dengan sendirinya membuka peluang kesempatan kerja di sektor tersebut yang pada akhirnya dapat memberikan peningkatan pendapatan masyarakat itu sendiri.

Hal tersebut di atas dapat tercipta dengan baik bergantung pada upaya dan kerjasama yang dilakukan pemerintah bersama pihak stakeholders di bidang kepariwisataan. Untuk itu, perlu ditetapkan kebijakan-kebijakan yang bertujuan untuk mendorong pengembangan kegiatan pariwisata. Kebijakan-kebijakan tersebut harus mengakomodir prinsip-prinsip pariwisata berkelanjutan seperti yang tertuang dalam Pacific Ministers Conference on Tourism and Environment di Maldivest tahun 1997 yang meliputi kesejahteraan lokal, penciptaan lapangan kerja, konservasi sumber daya alam, pemeliharaan dan peningkatan kualitas hidup, dan equity inter dan antar generasi dalam distribusi kesejahteraan (Dirjen-pariwisata,2004)

\section{B. Permasalahan yang Dihadapi}

Mencermati uraian di atas dapat diketahui bahwa permasalahan yang dihadapi oleh pemerintah dalam pengembangan kawasan wisata di Indonesia antara lain, sebagai berikut :

1. Keterbatasan dukungan sarana dan prasarana penunjang merupakan juga salah satu permasalahan yang perlu mendapat perhatian. Dimana dukungan sarana dan prasarana merupakan faktor penting untuk keberlanjutan penyelenggaraan kegiatan pariwisata, seperti penyediaan akses, akomodasi, angkutan wisata, dan sarana prasarana pendukung lainnya. Masih banyak kawasan wisata yang sangat berpotensi tetapi masih belum didukung oleh sarana dan prasarana yang memadai. Selain itu sarana dan prasarana yang dibangun hanya untuk kepentingan lokal saja, belum dapat 
melayani kebutuhan penyelenggaraan pariwisata di luar lokasi. Seperti misalnya penyediaan angkutan wisata hanya tersedia di area kawasan wisata saja, tetapi sarana angkutan untuk mencapai kawasan tersebut dari akses luar belum tersedia.

2. Terbatasnya biaya atau anggaran untuk pengembangan sektor wisata.

3. Belum tersedianya sumber daya manusia (SDM) yang betul-betul mampu melihat peluang maupun tantangan dari sektor kepariwisataan.

4. Belum terbinanya koordinasi antara lembaga-lembaga pemerintah daerah setempat dengan stakeholders bidang pariwisata. Misalnya keterkaitan dalam kerjasama antar pemerintah daerah dengan pengusaha pengelola objek wisata, hotel, restoran, transportasi, Telekomunikasi, pemandu wisata atau pramuwisata dan lain sebagainya.

5. Belum ada program pemasaran dan promosi pariwisata yang efektif, yang menggunakan pendekatan profesional, kemitraan antara swasta, pemerintah, dan masyarakat dan memperkuat jaringan kelembagaan, untuk meningkatkan kunjungan wisatawan baik wisatawan mancanegara maupun wisatawan nusantara

\section{Tujuan Penulisan}

Makalah ini mempunyai tujuan yaitu untuk mengidentifikasi dan menganalisa :

1. Kebijakan-kebijakan yang berkaitan dengan pembiayaan untuk pembangunan sarana dan prasarana dalam mengembangkan kawasan wisata.

2. Koordinasi antara lembaga-lembaga pemerintah dengan stakeholder yang terkait dengan bidang pariwisata.

3. Sumber daya manusia yang dibutuhkan dalam mengembangkan sektor pariwisata.

\section{Metodologi}

Penulisan makalah ini menggunakan pendekatan analisis deskriptif untuk mengidentifikasi permasalahan-permasalahan yang dikemukakan diatas, serta kajian literatur dari berbagai sumber informasi dan data yang kami peroleh sebagai acuan atau pedoman dalam menganalisis permasalahan-permasalahan tersebut.

\section{E. Teori dan konsep kepariwisataan}

Menurut arti katanya pariwisata berasal dari bahasa sansekerta yang terdiri dari dua kata yaitu kata pari dan wisata. Kata pari berarti penuh, seluruh atau semua kata wisata berarti perjalanan. Kata pariwisata dapat diartikan perjalanan penuh mulai dari berangkat dari suatu tempat ke satu atau beberapa tempat lain dan singgah kemudian kembali ke tempat semula. Dalam Undang-Undang No. 9 tahun 1990 tentang kepariwisataan (Bab IV pasal 4) disebutkan bahwa objek dan daya tarik wisata terdiri atas :

1. Objek dan daya tarik wisata ciptaan Tuhan Yang Maha Esa, yang berwujud keadaan alam serta flora fauna.

2. Objek dan daya tarik wisata hasil karya manusia berupa museum, peninggalan sejarah, wisata agro, wisata tirta, wisata buru, wisata petualangan alam, taman rekreasi dan tempat hiburan.

Sedangkan menurut Kuncoro (2001) menyatakan bahwa atraksi wisata dikelompokkan menjadi dua, yaitu atraksi sumber daya alam dan atraksi buatan manusia.

1. Atraksi wisata alam adalah setiap ekosistem dan segala isinya. Sumberdaya alam fisik dan hayati merupakan atraksi wisata yang dapat dikembangkan untuk objek wisata alam. 
Gea. Jurnal Pendidikan Geografi, Volume 8, Nomor 1, April 2008.

2. Atraksi buatan manusia meliputi atraksi budaya (agama, budaya modern, museum, galeri seni, situs arkeologi, bangunan), tradisi (kepercayaan, animasi budaya, festival) dan peristiwa olahraga (olimpiade, piala dunia, turnamen).

Kawasan pariwisata berdasarkan UU No. 47 tahun 1997 tentang Rencana Tata Ruang Wilayah Nasional pasal 11 ayat (1) merupakan salah satu dari sembilan kawasan budidaya. Kawasan pariwisata itu sendiri berdasarkan UU tersebut pada pasal 49 memiliki kriteria sebagai berikut :

a. Kawasan yang secara teknis dapat digunakan untuk kegiatan pariwisata, serta tidak mengganggu kelestarian budaya, keindahan alam, dan lingkungan;

b. Kawasan yang apabila digunakan untuk kegiatan pariwisata secara ruang dapat memberikan manfaat:

1. Meningkatkan devisa dan mendayagunakan investasi;

2. Meningkatkan perkembangan pembangunan lintas sektor dan sub sektor serta kegiatan ekonomi sekitarnya;

3. Tidak mengganggu fungsi lindung;

4. Tidak mengganggu upaya pelestarian sumber daya alam;

5. Meningkatkan pendapatan masyarakat;

6. Meningkatkan pendapatan nasional dan daerah;

7. Meningkatkan kesempatan kerja;

8. Melestarikan budaya;

9. Meningkatkan kesejahteraan masyarakat.

Pembangunan sektor kepariwisataan menurut Spillane (1994:14) akan terkait dengan aspek social budaya, politik dan ekonomi yang diarahkan untuk meningakatkan kesejahteraan masyarakat. Hal ini sejalan dengan konsep pembangunan kepariwisataan nasional sebagaimana tertuang dalam Undang-Undang no. 9 tahun 1990 disebutkan bahwa penyelenggaraan kepariwisataan ditujukan untuk meningkatkan pendapatan nasional dalam rangka kesejahteraan dan kemakmuran rakyat melalui perluasan dan pemerataan kesempatan berusaha dan bekerja serta memdorong pembangunan infrastruktur daerah dalam rangka kemudahan untuk memperkenalkan dan mendayagunakan obyek dan daya tarik wisata. Disamping itu pembangunan kepariwisataan juga dimaksudkan untuk memupuk rasa cinta tanah air dan memparerat persahabatan umat manusia dalam negeri dan antar bangsa.

\section{F. Peranan Pendidikan Dalam Meningkatkan Kemampuan Sumber Daya Manusia Dalam Pengembangan Kawasan Wisata}

Manusia adalah unsur terpenting dalam keberhasilan suatu organisasi. Dikatakan Susanto (1997) bahwa asset organisasi terpenting dan harus diperhatikan oleh menejeman adalah manusia (sumber daya manusia "human resources"). Hal ini bermuara pada kenyataan diman manusia merupakan elemen yang selalu ada dalam setiap organisasi. Manusia membuat tujuan-tujuan inovasi dan pencapaian tujuan organisasi. Manusia merupakan satu-satunya sumber daya yang dapat membuat sumber daya organinasi lainnya bekerja dan berdampak langsung terhadap kesejahteraan perusahaan.

Dalam kaitan ini menurut Tjokrowinoto dkk. (2001) bahwa figur atau sosok sumberdaya manusia pada abad 21 adalah manusia-manusi yang memiliki kualifikasi sebagai berikut : 
1. Memiliki wawasan pengetahuan (knowledge), ketrampilan (skill), dan sikap atau perilaku (attitude) yang relevan dan mampu menunjang pencapaian sasaran dan bidang tugas dalam suatu organisasi.

2. Memiliki disiplin kerja, dedikasi dan loyalitas yang tinggi terhadap pekerjaan dan terhadap organisasi.

3. Memilki rasa tanggungjawab dan pengertian atau pemahaman yang mendalam terhadap tugas dan kewajibanya sebagai karyawan atau unsure manajemen organisasi.

4. Memiliki jiwa kemauan yang kuat untuk berprestasi produktif dan bersikap professional.

5. Memilki kemauan dan kemampuan untuk selalu mengembangkan potensi dan kemampuan diri pribadi demi kelancaran pelaksanaan tugas organisasi.

6. Memiliki kemampuan yang tinggi dalam bidang tehnik maupun manajemen dan kepemimpinan.

7. Memiliki keahlian dan ketrampilan yang tertinggi dalam bidang tugas dan memiliki kemampuan alih teknologi.

8. Memiliki jiwa kewirausahaan (enterpreneurship) yang tinggi dan konsisten

9. Memilki pola pikir dan pola tindak yang sesuai dengan visi, misi, dan budaya kerja organisasi.

Pendidikan kepariwisataan merupakan salah satu kunci dalam mengembangkan potensi kepariwisataan (kawasan wisata), karena bidang ini memerlukan tenaga kerja terampil yang secara terus menerus harus dikembangkan. Menurut Spillane James. J (1994):"Salah satu masalah dalam mengembangkan pariwisata adalah tidak tersedianya fasilitas yang cukup untuk menunjang pendidikan pariwisata. Tenaga kerja yang cakap, terampil, memiliki skill tinggi dan pengabdian pada bidangnya(professional) menjadi kebutuhan mutlak dalam bersaing di pasaran global. Produk industri pariwisata adalah "jasa", oleh karena itu penekanannya harus pada segi pelayanan yang disesuaikan dengan kebutuhan wisatawan. Dalam industri pariwisata, kualitas pelayanan merupakan indikator utama yang menunjukkan tingkat professionalnya.

Pengembangan pengetahuan tenaga kerja ditekankan pada 3 hal pokok (Warsitaningsih, 2002):

1. Pengembangan pengetahuan tentang tata cara pelayanan yang berkaitan dengan bervariasinya kegiatan pariwisata, misalnya pelayanan di hotel, berbeda dengan pelayanan di tempat rekreasi atau dalam perjalanan wisata.

2. Pengembangan pengetahuan tentang peralatan dan perlengkapan yang diperlukan dalam bidang pelayanan.

3. Pengembangan SDM yang berkaitan dengan pengembangan sikap, perilaku, sopan santun, dan sebagainya.

Ketiga hal tersebut setiap saat selalu berubah dan mengarah pada kemajuan, sehingga ketiganya harus selalu ditingkatkan khususnya melalui pendidikan, yang juga akan mempengaruhi daya serap industri.

Daya serap industri pariwisata adalah kemampuan industri pariwisata dalam menyerap dan menerima karyawan yang berasal dari lembaga pendidikan umum dan pendidikan kejuruan untuk bekerja dalam lingkup pekerjaan kepariwisataan. Kemampuan menyerap karyawan di indistri pariwisata dipengaruhi oleh faktor-faktor sebagai berikut :

1. Besar kecilnya industri, besar kecilnya industri pariwisata akan menentukan jumlah dan jenis pekerjaan yang membutuhkan karyawan, sehingga akan menentukan pula besarnya daya serap industri pariwisata tersebut.

2. Ketersediaan calon tenaga kerja, lembaga pendidikan umum maupun pendidikan kejuruan merupakan tempat penghasil tenga kerja, misalnya melalui lembaga-lembaga formal (sekolah-sekolah pariwisata baik di tingkat menengah maupun di tingkat 
perguruan tinggi) dan non formal(pelatiahan-pelatihan kepariwisataan, kursus-kursus, dan lain-lain).

3. Kesesuaian kemampuan calon tenaga kerja denga bidang pekerjaan, seleksi yang ketat merupakan ssalah satu cara untuk menyerap karyawan professional artinya memiliki kemampuan sesuai dengan bidang pekerjaan yang diperlukan serta dapat menentukan besarnya daya serap industri pariwisata tersebut.

4. Kondisi ekonomi, merupakan faktor utama yang menentukan besarnya daya serap suatu industri terhadap lulusan lembaga pendidikan. Situasi krisis ekonomi saat ini merupakan salah satu faktor penyebab rendahnya daya serap industri pariwisata

Dengan demikian dari keseluruhan dimensi yang ada, maka terlihat bahwa sumberdaya manusia bertumpu pada dua indikator penting yaitu tingkat pendidikan yang dimiliki oleh para karyawan dan tingkat keterampilan yang berkaitan dengan bidang kerja yang ditangani karyawan tersebut.

\section{G. Konsep dan Praktek Good Governance}

Makna pemerintahan (governance) yang baik atau bersih harus dipahami sebagai suatu mekanisme pengelolaan sumber daya ekonomi dan sosial yang melibatkan pemerintah (negara) dan pihak non pemerintah (termasuk masyarakat warga yang sadar akan hak-hak demokratisnya) dalam suatu kerja yang keras secara bersama tanpa ada satu pihak yang mendominasi pihak lain (Stoker 1998; Ganie rohman 2000). Dengan demikian para pelaku pengelola sumber daya ekonomi dan sosial yang non pemerintah mempunyai wewenang untuk berpartisipasi secara penuh (pengambilan keputusan) baik dalam proses perencanaan, pelaksanaan pembangunan, memanfaatkan, maupun dalam melakukan pengawasan, evaluasi, atau kontrol (Uphoff dan Cohen 1979). Yang perlu diperhatikan ialah bahwa dalam kerja sama tersebut masing-masing pihak harus secara konsisten mematuhi aturan-aturan yang dibentuk dan disepakati bersama. Makna diatas membawa kita kepada tujuh persyaratan utama agar terjadi suatu "pemerintahan" yang bersih, menurut Mardiasmo (2004)

(1) Accountability (Pertanggung jawaban);

(2) Partisipasi;

(3) Fairness (keadilan dan "kebersihan");

(4) Transparancy (keterbukaan);

(5) Responsibility (bertanggungjawab);

(6) Otonomy (kemandirian) dan Freedom (kebebasan); dan

(7) Efisiensi dalam alokasi sumber daya.

Menurut World Bank (2001) dalam Kuncoro, Mudrajad (2004) dampak dari lemahnya governance adalah:

1. Kaum miskin tidak mendapatkan akses pelayanan publik yang dibutuhkan karena birokrasi yang korup.

2. Para investoe takut dan enggan menanam modal di Indonesia karena ketidak mampuan sistem peradilan untuik melaksanakan kontrak, meningkatnya kerusuhan, dan tingkat pelanggaran hukum dan keamanan yang tinggi.

3. Sumberdaya pemerintah yang langka banyak yang hilang karena sistem manajemen keuangan dan pengadaan barang yanga tidak transparan, manipulatif, dan banyak kebocoran.

Salah satu kualitas sumber daya birokrasi yang dituntut oleh good governance adalah kualitas kewirausahaan yang dapat memjembatani antara Negara dan pasar. Kualitas kewirausahaan birokrasi diperlukan untuk mengintervensi pasar secara selektif untuk menjamin berfungsinya 
pasar secara sehat. Menurut Tjokrowinoto dkk. (2001) Kompetensi yang perlu dimiliki oleh seorang birokrat berkaitan dengan hal tersebut mencakup :

1. Sensitif dan responsif terhadap peluang dan tantangan baru yang timbul didalam pasar.

2. Tidak terpaku dalam kegiatan-kegiatan rutin yang terkait dengan fungsi instrumental birokrasi, akan tetapi harus mampu melakukan terobosan melalui pemikiran yang kreatif dan inovatif.

3. Mempunyai wawasan futuristik dan sistematik.

4. Mempunyai kemampuan untuk mengantisipasi, memperhitungakan dan meminimalkan resiko.

2. Jeli terhadap potensi dan sumber-sumber dan peluang baru.

3. Mempunyai kemampuan untuk mengkombinasikan sumber menjadi resource mix yang mempunyai produktivitas tinggi.

4. Mempunyai kemampuan untuk mengoptimalkan sumber yang tersedia, dengan menggeser sumber kegiatan yang berproduktivitas rendah menuju kegiatan yang berproduktivitas tinggi.

Kompetensi birokrasi lain yang dituntut oleh good governance adalah kemampuan atau skill untuk mengerjaklan tugas-tugas pengelolaan di instansi masing-masing. Mengenai hal ini Adil Khan dan Meier (dalam Hessel Nogi S. 2002) mengemukakan bahwa good governance merupakan cara mengatur pemerintahan yang memungkinkan layanan publiknya efisien, sistem pengadilanya bias dialdalkan dan administrasinya bertanggungjawab pada public. Dari definisi yang telah disebutkan tadi setidak-tidaknya ada 2 kompetensi yang harus dimiliki oleh birokrasi. Pertama, birokrasi haruslah mampu memberikan pelayanan publik dengan adil dan inklusif sebaik-baiknya. Hal ini menuntut kemampuan untuk memahami dan mengartikulasikan aspirasi dan kebutuhan masyarakat, dan merumuskannya dalam kebijakan dan perencanaan serta mengimplimentasikannya. Kedua, birokrasi harus mempunyai kompetensi untuk memberdayakan masyarakat sipil dengan menciptakan kemampuan social.

Keseluruhan upaya tersebut diharapkan dapat mewujudkan kualitas manusia Indonesia (khususnya aparatur pemerintah) dalam manajemem pembanguanan yakni mereka yang memiliki tiga kualifikasi sebagai berikut : Pertama, melekatnya sifat-sifat loyalitas dedikasi dan motivasi kerja dalam mengemban tugas-tugasnya. Kedua, dimilikinya keahlian dan kemampuan professional dan Ketiga, dilaksanakanya sikap-sikap mental yang berorientasi pada etos kerja yang tertip, jujur, bisiplin, produktif dan bekerja tanpa pamrih.

\section{H. Koordinasi dan Kerjasama Antar Stakeholder Dalam Pengembangan Kawasan Wisata}

Pengertian koordinasi menurut Stoner (dalam Dann Sugandha, 1988) adalah proses penyatu paduan sasaran-sasaran dan kegiatan dari unit-unit yang terpisah untuk mencapai tujuan organisasi secara efisien.

Sedangkan Leonard D.White (dalam Sutarto, 1998) mendefinisikan koordinasi sebagai penyesuaian diri dari berbagai satuan organisasi dalam setiap kegiatan sehingga masingmasing bagian memberikan sumbangan yang optimal pada hasil secara keseluruhan.

Kesimpulan dari pendapat dua ahli administrasi tersebut di atas adalah sebagai berikut :

1. Suatu unit dalam organisasi tidak dapat berfungsi dengan baik tanpa bantuan dari unit lainnya.

2. Untuk mencapai tujuan organisasi maka tiap unit berkewajiban mendukung pelaksanaan fungsi dari unit lainnya secara menyeluruh dan terpadu. 
Konsep koordinasi didalamnya terkandung kebutuhan akan integrasi, komunikasi dan pelaksanaan tugas serta saling ketergantungan antar unit-unit organisasi. Hani Handoko (1995) mengemukakan tiga komponen dasar yang harus diperhatikan sebagai mekanisme dasar bagi pencapaian koordinasi yang efektif sebagai berikut :

1. Hierarki manajerial yaitu rantai perintah, aliran informasi dan kerja, wewenang formal, hubungan tanggung jawab dan akuntabilitas yang jelas dapat menumbuhkan integrasi bila dirumuskan secara jelas serta dilaksanakan dengan pengarahan yang tepat.

2. Aturan dan prosedur yaitu keputusan-keputusan manajerial yang dibuat untuk menangani kejadian-kejadian rutin, sehingga dapat menjadi peralatan yang efisien untuk koordinasi dan pengawasan rutin.

3. Rencana dan penetapan tujuan yaitu sebagai alat koordinasi dengan cara pengarahan kepada seluruh unit organisasi yang ada.

Dengan demikian dapat diperoleh manfaat dari pelaksanaan koordinasi secara terpadu dan sistematis (Sutarto, 1998) adalah sebagai berikut :

1. Menghindari pendapat atau perasaan penting dari salah satu unit organisasi.

2. Menghindari perasaan saling lepas antar organisasi.

3. Menghindari pertentangan antar pejabat atau antar unit organisasi yang ada.

4. Menghindari perebutan fasilitas yang dimiliki oleh organisasi.

5. Menghindari terjadinya saling tunggu antar unit organisasi.

6. Menghindari kekembaran pengerjaan terhadap suatu kegiatan organisasi, sekaligus kekosongan pengerjaan.

7. Terjadinya kesatuan langkah, tindakan, sikap an saling membantu antar pejabat atau unit organisasi yang ada.

Dari pendapat para ahli organisasi dan manajemen tersebut di atas dapat diambil kesimpulan mengenai beberapa aspek penting dari konsep penerapan koordinasi sebagai berikut :

1. Terdapat unit-unit organisasi maupun individu yang mempunyai fungsi yang berbeda dalam rangka penyelenggaraan organisasi secara keseluruhan.

2. Terdapat bermacam sumberdaya antara lain, tenaga kerja, keterampilan dan pengetahuan anggota teknologi, anggaran serta fasilitas kerja lainnya yang berperan terhadap keberhasilan organisasi.

3. Ada serangkaian kegiatan yang dilakukan oleh individu maupun unit organisasi yang ada.

4. Ada kesatu-paduan diantara seluruh kegiatan baik pada level individu maupun pada unit organisasi.

5. Ada keserasian karena kegiatan itu dilakukan menurut sistematika, waktu pengerjaan dan menghindari kekosongan serta duplikasi kegiatan organisasi.

6. Terdapat arah yang sama dari keseluruhan unit organisasi untuk sama-sama bergerak pada sasaran atau tujuan yang sama.

7. Dengan adanya koordinasi yang baik antara lembaga-lembaga pemerintah, stakeholder terkait dan masyarakat, diharapkan dapat terjalin jerjasama yang erat untuk mencapai tujuan yang diharapkan.

\section{Kesimpulan dan rekomendasi}

Pengembangan kawasan wisata di Indonesia muncul sebagai industri baru yang diharapkan dapat mendongkrak pendapatan nasional maupun daerah, sehingga pemerintah berupaya keras untuk mengembangkan sektor ini dalam rangka untuk mensejahterakan rakyat. Oleh karena itu pengelolaan, pengembangan, dan pembiayaan kawasan wisata memerlukan daya dukung dari banyak stakes holder (public, private, dan society) sehingga prosesnya bisa berjalan dengan lancar. Namun demikian keberhasilan pengembangan kawasan ini juga sangat dipengaruhi oleh kondisi stabilitas keamanan dan politik, daya dukung sumberdaya 
manusia yang memiliki keahlian yang sesuai baik segi kualitas maupun kuantitasnya, adanya anggaran yang digunakan untuk mengembangkan sarana dan prasarana kawasan wisata, kebijakan hukum yang memberikan kemudahan, keamanan, transparansi dan kenyamanan bagi para investor maupun wisatawan dalam menanamkan modal dan menikmati kawasan wisata, serta sosialisasi dan promosi atas pengembangan dan pemanfaatan kawasan wisata.

Berdasarkan hasil identifikasi dan analisis terhadap permasalahan-permasalahan yang diuraikan diatas, kami dapat merekomendasikan hal-hal yang perlu diperhatikan dalam mengembangkan kawasan wisata, sebagai berikut :

1. Percepatan pemulihan stabilitas politik dan keamanan dalam negeri sehingga diharapkan dapat menghapus stigma keberadaan teroris di Indonesia. Hal ini akan berpengaruh terhadap menguatnya tingkat kepercayaan kepariwisataan di Indonesia. Dengan demikian diharapkan akan meningkatkan daya tarik bagi para wisatawan maupun para investor lokal maupun mancanegara untujk berkunjung atau menanamkan modalnya dalam sektor pariwisata di Indonesia.

2. Sektor pariwisata merupakan sektor tersier dimana preferensi wisatawan sangat ditentukan oleh tingkat kenyamanan, maka dukungan sarana dan prasarana untuk meningkatkan aksesibilitas ke lokasi obyek wisata mutlak dibutuhkan. Pengembangan jaringan transportasi nasional, wilayah, dan lokal untuk mendukung pengembangan pariwisata terutama terkait dengan arahan pengembangan jaringan transportasi darat, laut, dan udara, termasuk juga arahan pengembangan alokasi bandara dan pelabuhan.

3. Meningkatkan kualitas dan kuantitas sumberdaya manusia sebagai pelaku kebijakan dalam bidang kepariwisataan melalui jenjang pendidikan yang bersifat formal maupun non formal. Sehubungan dengan hal tersebut, maka system dan mekanisme pendidikan dan latihan (diklat) perlu di desain secara baik, sehingga dapat menjawab tantangan kebutuhan di masa yang akan datang, khususnya tuntutan menciptakan aparatur yang memiliki keunggulan kompetitif, bersih dan berwibawa, handal serta efektif dan efisien.

4. Mengembangkan kemitraan dengan lembaga pendanaan (bank maupun non-bank) baik lembaga pemerintah maupun swasta untuk menciptakan investasi baru dalam rangka mengembangkan daerah tujuan wisata.

5. Untuk mencapai keberhasilan pengembangan kegiatan pariwisata, harus dilakukan secara koordinatif dan terpadu antar semua pihak yang terkait sehingga terwujud keterpaduan lintas sektoral dan menghindari terjadinya konflik antar sektor. Peningkatan keterkaitan fungsi pengembangan kegiatan pariwisata yang baik dengan sektor lainnya untuk memberikan nilai efisiensi yang tinggi dan percepatan pertumbuhan ekonomi wilayah. Pengembangan pariwisata harus dikaitkan dengan pengembangan ekonomi nasional, wilayah dan lokal. Pada tingkat nasional sektor pariwisata harus berperan sebagai prime mover dan secara interaktif terkait dengan pengembangan sektor-sektor lainnya. Pengembangan pariwisata harus diupayakan dapat melibatkan seluruh stakeholder. Dalam konteks ini peran masyarakat terlibat dimulai sektor hulu (memberikan kegiatan produksi yang ekstraktif) sampai dengan kegiatan hilir (kegiatan produksi jasa).

6. Peningkatan peran serta masyarakat dalam pengembangan pariwisata dan pelaksanaan pembangunan. Dalam menyelenggarakan kegiatan pariwisata harus melibatkan masyarakat setempat, sehingga manfaatnya dapat dirasakan langsung oleh masyarakat.

7. Melaksanakan program-program promosi yang efektif secara berkesinambungan, untuk meningkatkan jumlah kunjungan wisata baik wisatawan manca Negara maupun wisatawan nusantara.

\section{J. DAFTAR PUSTAKA}


.2006. Undang-Undang No. 32 tahun 2004 tentang Pemerintah Daerah. Bandung. Fokus Media.

..........1999. Kurikulum SMK, Landasan, Program, dan Pengembangan. Jakarta. Depdikbud.

........2007. Undang-Undang No. 26 tahun 2007 tentang Penataan Ruang. Bandung Fokus Media.

Djojonegoro, Wardiman. 1998. Pengembangan Sumbedaya Manusia melalui Sekolah Menengah Kejuruan (SMK). Jakarta. P.T. Jayaklarta Agung Offset.

Kuncoro, Mudrajad, 2004. Otonomi Daerah dan Pembangunan Daerah, Jakarta, Erlangga Mardiasmo. 2004. Otonomi dan Manajemen Keuangan Daerah. Yogyakarta. Penerbit Andi. Marpaung, Happy, 2002. Pengantar Pariwisata. Bandung, Alfabeta Bandung.

Spillane, James,J.S.J. Pariwisata Indonesia, Siasat Ekonomi dan Rekayasa Kebudayaan. Yogyakarta, Kanisius.

www.bappenas.go.id. 2007.Konsep dan Praktek Good Governance. Jakarta www.mail.archive. Com. 2007. Lingkungan Strategis dan Permasalahan Pembangunan

Bidang Kesra. Jakartra. Kementerian Koordinator Bidang Kesejahteraan Rakyat. www.setneg.go.id.2007. Strategi dan Kebijakan Pembangunan Kebudayaan dan Pariwisata 